Historia i Polityka

Półrocznik poświęcony myśli politycznej i stosunkom międzynarodowym

$\operatorname{Nr} 9(16) / 201359-70$

DOI: http://dx.doi.org/10.12775/HiP.2013.004

Małgorzata Madej (Wyższa Szkoła Handlowa we Wrocławiu)

\title{
The course and meaning of the Petersberg operations by the Western European Union
}

\author{
The course and meaning of the Petersberg operations \\ by the Western European Union
}

Peacekeeping operations are nowadays an important phenomenon in international relations and especially in conflict-ridden regions. The concept and framework of such operations has been constantly evolving in the past and one of the milestones of this evolution was the fall of the communist system and the end of the cold war. In Europe, this historic moment coincided with establishment by the Maastricht Treaty of the new organism within the process of western Europe's integration: the European Union.

Both these facts triggered a reaction of the somewhat passive and hardly visible European defence organisation of the Western European Union. Its Petersberg Declaration of 1992 redefined security and sought to change peace obligations of the member states of WEU, as they accepted a broader responsibility and a broader concept of security in the European region. This was an important first step in making defence integration a part of the mainstream integration process.

On the legal basis of the Petersberg Declaration, six operations were carried out. The paper discusses them, showing striking similarities, which actually comprise a special philosophy of intervention by WEU. This philosophy reflects both strengths and weaknesses of WEU's role in the European integration.

Słowa klucze: Misja Petersberska, Unia Zachodnioeuropejska, działania na rzecz pokoju Unii Zachodnioeuropejskiej, bezpieczeństwo w Europie

\section{Introduction (Western European Union)}

Western Union was among the first European integration organisations as it was established in 1948. Although the establishing Brussels Treaty ${ }^{1}$ contemplated a very broad scope of cooperation, the actual focus was on common defence,

1 Treaty of Economic, Social and Cultural Collaboration and Collective Self-Defence 1948 (Brussels Treaty), http://www.ena.lu/ (dostęp: 12.05.2013 r.). 
especially "to take such steps as may be held to be necessary in the event of a renewal by Germany of a policy of aggression" 2 . As this aim was actually achieved and Germany was turned into an important ally in the cold war, it was admitted to the organisation. The Western Union was then renamed to the Western European Union by the Modified Brussels Treaty ${ }^{3}$. Members of the organisation were European non-neutral countries participating also in the mainstream economic integration of the European Coal and Steel Community and European Economic Community. Its political and economic output was gradually included in the EEC's and European Union's acquis communautaire until finally it was incorporated in the Lisbon Treaty on European Union in its art. 42.74. Then with its mission transferred to the EU, WEU was officially dissolved 5 .

The WEU did not play an essential role in ensuring security in Europe, as this required involvement of the USA as a superpower during the cold war. However, it was used by its member states as a test platform for various solutions ${ }^{6}$, and sometimes quite ambitious ones. Below, I shall discuss the WEU's Petersberg Declaration, showing how important it was for re-defining the concept of security in the post-cold war Europe.

\section{Petersberg Declaration}

\section{Content}

The Petersberg Declaration ${ }^{7}$ was the WEU's reaction to establishment of the European Union (importantly, the Maastricht Treaty was the first to create the common European foreign and defence policy and it mentioned expressly the WEU "which is an integral part of the development of the Union", called to

2 Ibidem.

3 Treaty of Economic, Social and Cultural Collaboration and Collective Self-Defence 1953 (Modified Brussels Treaty), http://www.ena.lu/ (dostęp: 12.05.2013 r.).

4 Treaty on European Union, Lisbon version, Official Journal of the European Union 2010/C $83 / 01$.

5 Statement of the Presidency of the Permanent Council of the WEU on behalf of the High Contracting Parties to the Modified Brussels Treaty, http://www.weu.int/ (dostęp: 12.05.2013 r.).

6 e.g. DeVore M. R., A convenient framework: the Western European Union in the Persian Gulf, 1987-1988 and 1990-1991, European Security 2009, Vol. 18 Issue 2.

7 Western European Union Council of Ministers Petersberg Declaration, http://www.weu.int/, (dostęp: 1.08.2011 r.).

8 Treaty on European Union, Maastricht version, Official Journal of the European Union, 1992/C 191/01, art. J.4. 
support the member states in development and implementation of the common policy.

The Declaration was approved as early as 4 months after signing of the Maastricht Treaty which was short after the collapse of the Soviet Union. The member states of the WEU welcomed creation of the new European organisation and resolved to define new tasks for the WEU. In the post-cold war era the Western European countries extended the concept of the organisation: "apart from contributing to the common defence in accordance with Article 5 of the Washington Treaty and Article V of the modified Brussels Treaty respectively, military units of WEU member States, acting under the authority of WEU, could be employed for:

- humanitarian and rescue tasks;

- peacekeeping tasks;

- tasks of combat forces in crisis management, including peacemaking"'.

This policy was carried out during the 1990s and reflected in several operations. Their meaning was not entirely military, it was rather the political aspect of Europe's activity that mattered. Several characteristic features of this activity can be distinguished and they are typical of involvement by the WEU and EU itself in those times.

\section{Meaning}

Similar as in the case of its establishment in 1948 and of accession of Germany in 1953, the WEU in 1992 was used by its member states as an arena to test innovative solutions in integration, possible reactions to the changing international situation. In the case of the Petersberg Declaration, the innovativeness consisted especially in two points:

- extension of the concept of security to go beyond the idea of military balance of powers, advantage or alliances: the Petersberg Declaration was the first official document by the Western European countries to indicate that maintenance of stability and peace in other states is a precondition of peace in Europe; the idea of "humanitarian, peacekeeping and rescue operations" wandered clearly away from the cold-war domination concept of opposing to the other bloc and perceiving defence operations as containment or overpowering of the military potential of adversaries;

9 Western European Union Council of Ministers Petersberg Declaration, op. cit., art. II.4. 
in the Petersberg Declaration Europe took its idea of peace maintenance through stability and cooperation to the area of defence itself;

- geographical extension by obligation to take operations outside the area of the member states themselves; it took NATO another decade, until 2002, to approve out-of-area operations as an important too ${ }^{10}$. This was an important initiative of taking responsibility for the neighbouring regions, although it could have been linked to the "humanitarian intervention" concept. Actually, the WEU remained careful enough to avoid this concept, although this carefulness came at a price of a serious reduction of the practical meaning of the Declaration.

These concepts were verified and improved in former Yugoslavia and are now reflected in Europe's defence policies as well. The operations were also an opportunity to check Europe's ability to take responsibility independently or in parallel to the United States. In this case, the Petersberg operations proved that defence integration required a lot effort on Europe's part to adapt to the post-cold war world.

\section{Petersberg operations}

\section{Humanitarian and rescue tasks}

The point of humanitarian tasks is the focus on people living in the conflict area and by no incidence this form of intervention was listed first in the Declaration. The Modified Brussels Treaty envisaged promotion of human rights and democracy in the member states as one of its goals and the Petersberg Declaration went further to offer such assistance to third parties. The European Union provided financial and material support ${ }^{11}$, while the WEU was assigned with the task of technical assistance by military and security services. Financial aid often takes form of development assistance with the long-term goals to encourage economic and welfare growth in the country, while also a special event-related, emergency aid is sometimes directly needed ${ }^{12}$.

10 M. A. Smith, Afghanistan in Context: NATO Out-of-area Debates in the 1990s, UNISCI Discussion Papers 2010, No 22 (January / Enero).

11 European Union, http://ec.europa.eu/echo/index_en.htm (dostęp: 20.8.2013 r.).

12 J. Rubenstein, Distribution and Emergency, The Journal of Political Philosophy 2007, Volume 15, Number 3. 
Protection of the community is actually the task of the state, but sometimes aid is needed, if the government is incapable of sufficient action. This may be due to shortage of government's resources, deficient know-how and experience, scale of the threat. This is also the case of newly-established states, especially if their road to independence was conflict-ridden. Therefore, deeper involvement is often required than just counselling and finance.

\section{Demining Assistance Mission in Croatia}

The situation in the post-war Balkans in the 1990s was clearly an emergency one. The new states had to cope with the moral and physical heritage of the war. In February 1998, the government in Zagreb established a special agency Croatian Mine Action Centre (CROMAC) to identify and eliminate land mines in the state's territory, a left-over of the war, threatening citizens' life and public health, markedly compromised by the fights. The general aims of this agency consist in humanitarian demining based on direct demining and reduction of danger zones and therefore they require sophisticated equipment, data collection and procession instrument as well as staff expertise ${ }^{13}$.

The beginning of CROMAC's functioning was assisted by the Western European Union Demining Assistance Mission (WEUDAM) from May 1999 until November 2001, which provided for organisational and technical support and training ${ }^{14}$. The operation was initiated by the EU according to the Maastricht treaty and funded by the EU's budget, but organised and managed entirely by the WEU. One of the key achievements was invitation of neutral states to cooperation, with Sweden being even the lead nation of the operation ${ }^{15}$.

The Western European Union's assistance was not a broad operation, but it touched on crucial issues for the Croatian society. This support was essential for triggering the effective functioning of CROMAC ${ }^{16}$. Currently, completion of the demining operation is planned for 2019.

13 A. Krtalić, Thematic Maps for Humanitarian Demining, Cartography \& Geoinformation 2012, Vol. 11.

14 R. Zięba, Instytucjonalizacja bezpieczeństwa europejskiego, Warszawa 2001, s. 221.

15 Western European Union, http://www.weu.int/ (dostęp: 20.8.2013 r.).

16 CROMAC, http://www.hcr.hr/en/aktualnostCijela.asp?ID=1208 (dostęp: 20.8.2013 r.). 


\section{Peacekeeping tasks}

Peacekeeping is a concept of helping states and nations stay out of conflicts and avoiding wars. It is related to implementation of peace agreements, military conflict prevention, enforcement of state institutions and nation building. "The main objective is to render violent societies peaceful" ${ }^{17}$. Based on ideas of promoting stability, partnership and experience sharing, peacekeeping is an excellent reflection of ideas and provisions of the Petersberg Declaration, referring also to the very background of the European integration itself.

Importantly, peacekeeping tasks, though they involve military forces, are based on cooperation with the states concerned and even their consent. Thus, they are kept strictly within provisions of international law.

One of the forms of such assistance is training of the conflicted region's own services $^{18}$. Such operations help the local community prepare for independent functioning and ensuring security of inhabitants. The operation may include delivery of state-of-the-art technical equipment, training in its use and maintenance, but also organisational and institutional know-how.

\section{Sharp Guard at the Adriatic Sea}

"Sharp Guard" was the first operation based on the Petersberg Declaration, commenced in July 1992. The marine operation by WEU was meant to monitor and control compliance by the embargo imposed on the Federal Republic of Yugoslavia (including then the now Serbia, Kosovo and Montenegro) by resolutions of the UN Security Council. The WEU's intervention was triggered by the resolution no. 757 of 20.5.1992, forbidding any import of goods from Yugoslavia or delivery of any other goods than food and medical supplies there. The Council summoned all its member states to prevent any flights to Yugoslavia or back ${ }^{19}$. With restricted right of take-off, overfly and landing for all aircraft from or to Yugoslavia, other potential paths of delivery had to be considered, as well. Among them sea routes through Yugoslav ports on the Adriatic Sea played an important role.

The Western European Union used patrolling ship and aircraft at the Adriatic Sea, inspecting 6.000 vessels with 1.400 inspected at ports. Within the operation

17 J. Dobbins, Europe's Role in Nation Building, Survival 2008, vol. 50 no. 3, s. 85.

18 P. Burnell, From Evaluating Democracy Assistance to Appraising Democracy Promotion, Political Studies 2008 Vol. 56, s. 414-434, s. 417.

19 UN Security Concil Resolution no. 757 (1992), http://daccess-dds-ny.un.org/doc/RESOLUTION/GEN/NR0/011/16/IMG/NR001116.pdf?OpenElement, (dostęp: 7.9.2013 r.). 
six attempted breaches of the embargo were suppressed ${ }^{20}$. In 1993 „Sharp Guard” was joined with the NATO operation. This was actually a test of WEU's plans and potential. „Sharp Guard” revealed that the WEU had "neither the political will nor the military resources to conduct a policy independent of NATO"21. This experience was used in further Petersberg operations.

\section{Danube customs operations}

This was another operation related to enforcement of the embargo imposed by the United Nations. It covered regions in three states: Hungary, Bulgaria and Romania. In mid-1990s the international status of "post-communist" countries was not a stable one and they strived to redefine their position. This is why the involved riparian states requested support from the European Union and these support was provided by the WEU through cooperation with local forces ${ }^{22}$.

The form of this support was initiated and organised by the Western European Union: it was the organisation's decision to offer help in the form of no more than 250 personnel, organisation and coordination centre, as well as equipment deliveries $^{23}$. Between 1993 and 1996 the WEU's forces were responsible for coordination, control and support in the process of prevention of smuggling by river transport within the territory of three different countries. It was also an important test for those states in the pre-accession period.

The Danube operation was wound up after conclusion of the Dayton agreements and abolition of the embargo. Both the WEU itself and the riparian states found the operation successful as it managed to enforce the embargo and prevent its breach using the Danube water track ${ }^{24}$.

\section{Police contingent in Mostar}

The WEU's operations in the Western Balkans were by no means limited to enforcement of restrictive measures. In 1994-1996, in cooperation with the

20 http://www.weu.int/ (dostęp: 4.08.2013 r.).

21 R. Corsini, The Balkan War. What Role for Airpower?, Airpower Journal 1995, Vol. 9, Issue 4.

22 A. Chayes, A. H. Chayes, Preventing Conflict in the Post-communist World: Mobilizing International and Regional Organisations, Washington 1996.

23 Western European Union, op. cit.

24 D. Brown, The role of regional organizations in stopping civil wars, Air Force Law Review 1997, Vol. 41. 
European Union it took an action for stabilisation and democratisation in BosniaHerzegovina, focused on administration of one of the most conflict-ridden sites: the city of Mostar. The Western European Union supplied a small police contingent of no more than 200 persons, and its responsibilities included training and support of the municipal forces, consisting of Muslims and Croats. Special attention was paid to unification of multiethnical public order services and therefore the WEU forces themselves involved many different countries, both member states of the WEU and neutral countries ${ }^{25}$.

The mission was completed at the end of 1996, when the western European policemen handed the control over to the local forces ${ }^{26}$. However, its success was disputed: the Mostar authorities regained their power but the police forces were very far from being unified ${ }^{27}$.

A serious problem in this operation concerned unclear division of responsibilities between the WEU and the European Union. This was one of indications that sooner or later defence had to be incorporated in the main stream of the integration process.

\section{MAPE operation in Albania}

The crisis management operation in Albania (Multinational Advisory Police Element - MAPE) was held based on a common decision issued by the European Union according to art. J.4 of the Amsterdam Treaty. Art. J.7 of the Treaty provided that the EU had a right to entrust the WEU with implementation of such a decision ${ }^{28}$.

The point of the tasks was to support restructuring of internal security forces in Albania, focusing on police forces. WEU's role included counselling for Albanian authorities, as well as organisation of training for policemen. For this purpose, two police schools were established in Tirana and Durres. Financial support by the European Union ensured a possibility to improve infrastructure and equipment for Albanian police. As "MAPE" operation lasted from 1997 until 2001, it included support in the period of Kosovo crisis, when Albania had to help refugees from the neighbouring region ${ }^{29}$.

25 K. M. Osland, The EU Police Mission in Bosnia and Herzegovina, International Peacekeeping 2004, Vol. 11 Issue 3.

26 Western European Union, op. cit.

27 K. A Eliassen, Foreign and Security Policy in the European Union, Trowbridge 1998.

28 Treaty on European Union, Amsterdam version, Official Journal of the European Union, $1994 / \mathrm{L} / 37 / 01$.

29 Western European Union, op. cit. 
The operation's result was very controversial. On one hand, many researchers stressed that the WEU had not actually prepared the Albanians to take over responsibility for training and education of forced, not to mention ensuring efficiency of the Albanian forces, as shown by their failure during the Albanian crisis. The role of the WEU was discarded as irrelevant and insufficient ${ }^{30}$. On the other hand, it was also argued that "Ultimately, despite all its shortcomings, the WEU did address the most difficult and important mission in Albania" ${ }^{31}$. "MAPE" was an ineffective attempt of a non-military response to the region's instability and its weaknesses are characteristic of the WEU.

\section{Security surveillance in Kosovo}

The Western European Union was involved in the Kosovo conflict between the region's Albanian and Serbian directly, too. During the stage of non-military operations, before the NATO's intervention in 1999 and commencement of KFOR peacekeeping forces' operations, the western Europe attempted to control security and situation in Kosovo, focusing on the refugees. The WEU's action was very limited: its goal was to collect and process data to be provided further to the EU, NATO, UNO and other international organisations ${ }^{32}$. The most important tangible result of the mission was development of the Geographical Information System based on satellite data. This detailed imagery and multi-layer map was very important for redevelopment of infrastructure, development planning and demining of the area ${ }^{33}$.

The operation was meant as monitoring and technical assistance. It required a large technological and financial potential, but it was not a military action - that one was undertaken by NATO. This also shows the role assigned to the WEU.

\section{Tasks of combat forces in crisis management}

Although the Petersberg Declaration provided for such a possibility, the WEU never used combat forces in its peace operations. This fact was due to a range of reasons.

30 cf. Quick march! Who says?, Economist 22.3.1997, Vol. 342 Issue 8009.

31 S. Kay, From Operation Alba to Allied Force: Institutional Implications of Balkan Interventions, Mediterranean Quarterly1999, Vol. 10 Issue 4, s. 84.

32 Western European Union, op. cit.

33 F. Rosenstiel, E. Lejard-Boutsavath, J.-J. Martz, Annuaire Europeen, European Yearbook 1999. 
Firstly, the Western European Union was actually unable to do so due to its technological dependence on the US Army. Secondly, the WEU was only a tool meant to verify defence integration potential, while protection against any threats was and is ensured within NATO. Thirdly, the western European countries' colonialist heritage made it very hard for them to initiate even humanitarian external interventions and it took them almost two decades to accept such a responsibility in the case of the Libyan intervention. Fourthly, combat operations are much more dangerous - in the direct meaning of danger to soldiers' life, but also in the political aspect they are connected with a much more serious risk of internal opposition and external conflict. Such actions are not so easily planned their duration and costs are harder to predict.

With this combination of initial problems (getting a consent of the public opinion, parliament and international organisations), resources required (funding, equipment etc.) and risk involved (casualties and conflicts with other countries or regions), the WEU member states never resolved to commit their combat forces to any Petersberg operation.

\section{Characteristics of Petersberg operations}

The discussed operations shared a common legal basis of the Petersberg Declaration, took place in one region and they had more similarities, which is quite symptomatic of the Western European Union.

Firstly, although they were all "out-of-area" operations, they never went beyond Europe, unlike the 1988-1990 operations in the Gulf ${ }^{34}$. They were all symptomatically held in the close neighbourhood of the member states, showing their actual ambition to become a guarantee of peace and stability only for the region. This attitude is somewhat still visible in the 2010s with the European Union's defence effort focused on Northern Africa.

Secondly, all Petersberg operations were based on decisions made by other international organisations than the WEU, namely the EU and the UNO. The Western European Union was not an independent institution, but a tool used by its member states whenever they preferred to keep the economy-focused EU out of an undertaking.

Still these undertakings were not very controversial, since the WEU always sought to gain approval from the countries concerned. It was not involved in any

${ }_{34}$ W. Van Eekelen, The role of the WEU in European security, Harvard International Review, 1991, Vol. 14 Issue 1. 
campaigns that could induce some sort of resistance or military conflict. Even though the operations did take place in conflict areas, they were operations of support and not enforcement character. This does not actually show the European states' unwillingness to take more decisive action, since they participated in the NATO operation against Serbia in the very same 1999.

Similarly, the Western European Union's operations were all multinational. Even if the contribution of some states was very small, of several or a dozen specialists, the WEU still tried to involve as many countries as possible, including also neutral states. In one case a neutral, non-WEU state was even the lead nation of an operation ${ }^{35}$. This served as a tool to enhance multinational and multicultural management in the former Yugoslavia, but also supported the idea of European defence organisation.

And finally, as a reflection of those feature and the WEU's character, the operations were actually political, and defence ones - both for the organisation and countries concerned. It was the sheer fact of Europe's active involvement that was the essence of Petersberg operations. They were important as a symbol of cooperation between EU and non-EU states as well as of western Europe's commitment to stability in the entire region.

\section{Conclusions}

Petersberg operations did not make a difference in the region of former Yugoslavia, but they changed the European states' attitude to defence integration. They worked as a test platform for new solutions in the international cooperation, concerning such issues as:

- cooperation with the USA through an independent European defence structure

- cooperation with neutral countries on the margin of the European Union integration process

- cooperation with post-communist and especially post-Yugoslav countries

- accepting responsibility as stabiliser of the entire region

- enhancing internal stabilisation instead of enforcement

- specialist assistance instead of military or political involvement.

This was not a revolution, rather an attempt to organise and consolidate cold-war experiences in the new era. The importance of the Petersberg operations

35 Western European Union, op. cit. 
- and the WEU as a whole - lied in verification of some mechanisms without involvement of the main integration organisms of the EU and NATO. The mechanisms' inefficiencies and failures were exposed and yet the WEU lasted and was capable of limited operational activity.

WUE proved that a limited defence initiative by the European Union was viable, although it has never become a really efficient tool of international influence. The lesson of Petersberg operations resulted in the long term in incorporation of defence issues and mutual security guarantees in the Treaty on the European Union $^{36}$, but the most important defence interests of European countries are still dealt with elsewhere - mainly within the NATO and UNO frameworks. It is noteworthy that even after the Lisbon Treaty, the member states have not ceded their capacities in those bodies to the European Union as a whole.

Unless the European Union is able to define more strict and effective defence mechanisms, its integration in this area shall remain of little relevance as compared to other domains.

36 Treaty on European Union, Lisbon version, Official Journal of the European Union, 2010/C $83 / 01$. 